\title{
PENINGKATAN MOTIVASI DAN KOMPETENSI LATIHAN DASAR KEPEMIMPINAN MELALUI PENDEKATAN EDUTAINMENT DENGAN METODE OUTBOUND PADA MAHASISWA/I SEMESTER 1 DAN 2 PRODI SEKRETARI D-III TAHUN 2020 DI UNIVERSITAS PAMULANG
}

\author{
Unik Desthiani ${ }^{1}$ \\ Dosen Program Studi Sekretari D-III Universitas Pamulang \\ unikdesthiani@gmail.com \\ Ratna Suminar ${ }^{2}$ \\ Dosen Program Studi Sekretari D-III Universitas Pamulang \\ ratnasuminar2255@gmail.com
}

\begin{abstract}
ABSTRAK-Lembaga pendidikan yang ada di Indonesia sesuai dengan jenjangnya terdiri dari: pendidikan usia dini yaitu playgroup, paud dan TK, pendidikan tingkat menengah yaitu SMP dan SMA, serta perguruan tinggi. Konsep dari jenjang pendidikan tersebut pada dasarnya sama yakni mengembangkan manusia yang berintelektual, serta memiliki jiwa sosial kemasyarakatan. Pada jenjang pendidikan tinggi dalam pembentukan karakter perlu diberikan pengetahuan dan pendidikan yang memadai melalui organisasi kemahasiswaan yaitu Himpunan Mahasiswa Sekretari yang biasa disebut dengan HIMAS. HIMAS mempunyai banyak kegiatan salah satunya Latihan Dasar Kepemimpinan (LDK). LDK menjadi jembatan pemahaman program maupun lingkungan kampus perguruan/pendidikan bagi mahasiswa baru. Diharapkan LDK ini bisa menjadi sarana yang efektif untuk pembentukan karakter mahasiswa dalam berorganisasi. Melalui program LDK diharapkan dapat membentuk karakter dan sikap pentingnya memahami program dan lingkungan kampus dan menjadi motivasi tersendiri pengembangan kompetensi sumber daya manusia/mahasiswa. Latihan Dasar Kepemimpinan ini bisa dilakukan secara indoor ataupun outdoor. Tujuan dari penelitian ini adalah (1) Untuk mengetahui dan mendeskripsikan peningkatan motivasi mahasiswa semester 1 dan 2 Prodi Sekretari D-III dalam mengikuti latihan dasar kepemimpinan melalui edutainment dengan metode outbound, (2) Untuk mengetahui dan mendeskripsikan peningkatan kompetensi mahasiswa semester 1 dan 2 Prodi Sekretari D-III setelah mengikuti Latihan Dasar Kepemimpinan melalui edutainment dengan metode outbound. Penelitian ini dilakukan dengan menggunakan metode kualitatif. Data diambil dari hasil wawancara, observasi dan dokumentasi. Analisis data dilakukan dengan menggunakan empat (4) tahapan yaitu pengumpulan data, reduksi data, penyajian data dan penarikan kesimpulan.Secara teoritis hasil penelitian ini akan menambah khasanah ilmu pengetahuan khususnya dalam bidang pengembangan motivasi dan kompetensi latihan dasar kepemimpinan melalui pendekatan edutainment dengan metode outbound.
\end{abstract}

Kata kunci: Motivasi, Kompetensi, Latihan Dasar Kepemimpinan, Pendekatan Edutainment dengan metode outbound.

ABSTRACT - Educational institutions in Indonesia according to their levels consist of: early childhood education, namely playgroups, paud and kindergarten, secondary education, namely 
junior and senior high schools, and universities. The concept of this level of education is in fact the same as developing intellectual humans who have a social spirit. At the higher education level, character orders need to be given adequate knowledge and education through student organizations, namely the Secretarial Student Association which is commonly referred to as HIMAS. HIMAS has many activities, one of which is Basic Leadership Training (LDK). LDK is a bridge to understanding programs and the college / education campus environment for new students. It is hoped that this LDK can be an effective means of ordering student character in organization. Through the LDK program, it is hoped that it can shape character and understand the program and the campus environment and become a motivation for developing human / student competence. This Basic Leadership Training can be done indoors or outdoors. The objectives of this study were (1) To see and describe the increase in the motivation of students in semesters 1 and 2 of the D-III Secretarial Study Program in basic leadership training through edutainment with the outbound method, (2) To see and describe the increase in the competence of students in semesters 1 and 2 of Secretariat Study Program D-III after attending Basic Leadership Training through edutainment with the outbound method. This research was conducted using qualitative methods. Data taken from interviews, observation and documentation. Data analysis was carried out using four stages, namely the stages of how the data, data reduction, data presentation and drawing conclusions. Theoretically the results of this study will add to the knowledge of science, especially in the field of developing motivation and basic leadership training competencies through the edutainment approach with the outbound method.

Keywords: Motivation, Competence, Basic Leadership Training, Edutainment Approach with outbound methods.

\section{PENDAHULUAN}

\section{Latar Belakang}

Pendidikan baik tingkat awal, menengah maupun tinggi, memiliki konsep yang sama yaitu mengembangkan insan intelektual dan berjiwa sosial. Semua ini bertujuan untuk menciptakan generasi muda penerus cita-cita dan pembangunan bangsa. Salah satu watak untuk mewujudkan cita-cita tersebut adalah karakter individu yang baik termasuk jiwa kepemimpinan.

Kepemimpinan sendiri merupakan gaya atau seni untuk menjalankan dan menggerakkan roda organisasi ke arah dan visi yang telah ditentukan. Seorang pemimpin harus visioner, mampu memotivasi, mampu berkomunikasi secara efektif, mampu melahirkan kepercayaan, mampu memimpin dengan nilai-nilai terbaik, memiliki kemampuan menyelesaikan konflik dan berkarisma menghadapi berbagai situasi dan kondisi dinamis yang berbeda, mengarah pada perubahan.

Salah satu sarana untuk dapat memberikan ilmu dan pendidikan dalam pembentukan karakter mahasiswa yaitu pada level kepemimpinan melalui organisasi kemahasiswaan di kampus seperti Sekretaris Himpunan Mahasiswa biasa dikenal dengan HIMAS. Organisasi HIMAS memiliki 
banyak kegiatan, termasuk pelatihan kepemimpinan dasar. Pelatihan kepemimpinan dasar ini merupakan tahap atau persyaratan awal yang harus dilalui oleh setiap siswa yang ingin menjadi pengurus HIMAS.

Dengan mengikuti pelatihan dasar kepemimpinan, siswa mendapatkan pembinaan mental dan spiritual guna meningkatkan motivasi dan kompetensi siswa sebagai pemimpin dalam suatu organisasi. Dan dengan mengikuti Diklat Kepemimpinan Dasar ini diharapkan kredibilitas dan eksistensi mahasiswa senantiasa bermanfaat bagi lingkungannya pada umumnya maupun bagi organisasi pada khususnya.

Tempat pelaksanaan pelatihan kepemimpinan dasar dilaksanakan indoor dan outdoor. Kegiatan internal bertujuan untuk memberikan program pelatihan dasar kepemimpinan terpadu yang merupakan salah satu program kerja organisasi kemahasiswaan HIMAS untuk meningkatkan motivasi dan kompetensi sumber daya manusia mahasiswa. Sedangkan kegiatan dasar pelatihan kepemimpinan di luar ruangan adalah kegiatan atau acara seperti malam intim, kemah dengan kegiatan outbound gratis.

Outbound merupakan metode pendekatan hiburan pendidikan sedangkan edutainment adalah model pembelajaran yang digunakan dalam pendidikan dikombinasikan atau digabungkan dengan hiburan bagi peserta pelatihan kepemimpinan dasar agar tidak bosan dengan materi. Materi yang diberikan dalam kegiatan pelatihan kepemimpinan dasar berupa kepemimpinan, pengembangan karakter dan kerja sama tim. Pemberian materi dalam pelatihan kepemimpinan dasar berlangsung dalam forum diskusi biasa dan melalui berbagai tugas team building.

$$
\text { Walaupun pelatihan dasar }
$$

kepemimpinan ini dilaksanakan dengan konsep yang sangat beragam dan menarik namun hasil dari pelatihan dasar kepemimpinan ini khususnya dalam pelatihan karakter seperti semangat kepemimpinan pada siswa masih kurang ideal, sehingga melalui Laatihan Dasar Kepemimpinan diharapkan mampu membangun karakter dan sikap. Peneliti tertarik membahas mengenai:

" Peningkatan Motivasi Dan Kompetensi Latihan Dasar Kepemimpinan Melalui Pendekatan Edutainment Dengan Metode Outbound Pada Mahasiswa/i Semester 1 Dan 2 Prodi Sekretari D-III Tahun 2020 Di Universitas Pamulang”.

\section{Identifikasi Masalah}

1. Masih belum maksimal dalam pembinaan karakter seperti semangat 
kepemimpinan pada mahasiswa melalui pelaksanaan Diklat Kepemimpinan Dasar.

2. Peningkatan motivasi mahasiswa belum ideal padahal Pelatihan Dasar Kepemimpinan dilaksanakan dengan beberapa konsep yang menarik.

3. Peningkatan kemampuan mahasiswa dalam hal kepemimpinan masih belum optimal meskipun Diklat Kepemimpinan Dasar dilaksanakan dengan berbagai konsep yang menarik.

\section{Perumusan Masalah}

Berdasarkan identifikasi masalah sebelumnya, maka rumusan masalah tersebut dirumuskan sebagai berikut:

1. Apakah pendekatan hiburan pendidikan dengan metode outbond dapat meningkatkan motivasi mahasiswa 1 dan semester 2 mengikuti pelatihan kepemimpinan dasar?

2. Apakah pelatihan kepemimpinan dasar melalui pendekatan edutainment dengan metode outbound dapat meningkatkan kompetensi mahasiswa semester 1 dan 2 dalam hal kepemimpinan?

\section{Metode Penelitian}

Data yang dikumpulkan berupa data kuantitatif (untuk data kompetensi) dan data kualitatif (untuk data motivasi). Dalam penelitian ini penulis tidak menggunakan uji statistik tetapi dengan deskriptif komparatif yang dilanjutkan dengan refleksi yaitu penarikan kesimpulan berdasarkan perbandingan deskriptif.

\section{LANDASAN TEORI}

Motivasi Dasar Untuk Pelatihan
Kepemimpinan

\section{Sifat Motivasi}

Motivasi dalam Ngalim (2011: 69) Motif atau impuls merupakan dorongan yang menjadi titik awal seseorang untuk melakukan pekerjaan. Tujuan produksi unit kerja dan organisasi didukung oleh orang bermotivasi tinggi yang mau bekerja keras, begitupun sebaliknya. untuk mempelajari kinerja individu perlu memahami konsep motivasi, motivasi merupakan pemberian alasan, penciptaan alasan atau hal-hal yang memunculkan rangsangan atau keadaan yang menghasilkan rangsangan.

Manusia, dalam aktivitasnya biasa memiliki semangat untuk melakukan sesuatu, selama ia dapat menghasilkan sesuatu yang ia anggap sangat berharga dan dengan tujuan yang telah ditetapkan yaitu melanjutkan hidupnya, merasa nyaman, merasa aman dan begitu seterusnya. 
Motivasi Mengikuti Pelatihan

Kepemimpinan Dasar

Manusia dalam aktivitasnya yang biasa memiliki semangat untuk melakukan sesuatu selama ia dapat menghasilkan sesuatu yang ia anggap sangat berharga yang tujuannya tentu untuk mewujudkan hidupnya, perasaan damai, perasaan aman, sehingga motivasi sangat erat kaitannya dengan kebutuhan manusia yang mempunyai kebutuhan dan keinginan sehingga manusia selalu berusaha untuk memenuhi kebutuhannya.

Mahasiswa semester 1 dan 2 Sekretari D-III Universitas Pamulang wajib mengikuti tindak lanjut diklat kepemimpinan dasar yang diatur dalam pedoman dan jadwal pelaksanaan diklat kepemimpinan dasar yang harus diikuti selama pelatihan kepemimpinan dasar.

\section{Inti Dari Pelatihan Kepemimpinan Dasar}

Pelatihan Dasar Kepemimpinan (LDK) adalah pelatihan dasar dalam segala hal yang berkaitan dengan kepemimpinan. Kepemimpinan diartikan sebagai suatu cara mencapai tujuan organisasi melalui kerja orang lain. Ada beberapa dimensi dalam kepemimpinan diantaranya: kepemimpinan sebagai penggerak dan motivator dalam organisasi, kepemimpinan sebagai momentum pencapaian tujuan bersama.

Harapan setelah melaksanakan diklat kepemimpinan dasar dapat memperkuat kualitas kepemimpinan, keterampilan berorganisasi, kesadaran politik sebagai warga negara yang bertanggungjawab, mengembangkan dan memperluas wawasan dalam pelaksanaan tugas kepemimpinan, menstimulus mengarahkan dan membimbing potensi kepemimpinan, memperkuat kesadaran dan tanggungjawab sebagai generasi penerus bangsa, memperbaiki mentalitas, sikap, kepribadian, perilaku, karakter dan disiplin.

\section{Keterampilan Kepemimpinan Dasar Inti Dari Kompetisi}

Kapasitas atau kompetensi menurut Kapita Selekta Pendidikan dan Pelatihan Berbasis Kompetensi (2010:88) merupakan ciri dasar seseorang yang mempengaruhi cara berpikir, bertindak dan melakukan generalisasi tentang segala situasi yang dihadapinya dan berlangsung cukup lama. Keterampilan tersebut meliputi komponen, motif, karakter pribadi, konsep diri, pengetahuan dan keterampilan.

Peningkatan kapasitas atau kompetensi pendidikan dan pelatihan diklat berbasis kompetensi merupakan kegiatan pembelajaran fokus pada peningkatan 
kemampuan penyelesaian tugas yang ditentukan diperlukan untuk meningkatkan pengetahuan atau kompetensi seseorang agar dapat melaksanakan tugas yang lebih profesional.

\section{Keterampilan Kepemimpinan Dasar}

Pelatihan kepemimpinan dasar merupakan kegiatan yang diselenggarakan oleh Program Studi D-III Sekretari Universitas Pamulang dan bersifat wajib bagi mahasiswa semester 1 dan 2. Pelatihan kepemimpinan dasar bertujuan untuk meningkatkan kompetensi mahasiswa dalam memimpin organisasi. Dengan adanya pelatihan kepemimpinan dasar diharapkan pengelolaan kemahasiswaan dapat ditingkatkan di internal organisasi program studi, seperti Himpunan Mahasiswa Kesekretarisan (HIMAS).

Beberapa keterampilan dalam pelatihan kepemimpinan dasar yang ingin dicapai antara lain kemampuan berkolaborasi antar mahasiswa dalam organisasi, meningkatkan disiplin, dengan pelatihan kepemimpinan dasar diharapkan siswa dapat mengambil berbagai keputusan terkait dengan organisasinya dan membangun semangat.

\section{Pendekatan Pendidikan Hiburan Dengan Metode Outbound}

\section{Pendekatan Hiburan Pendidikan}

Menurut Sutrisno (2012: 20), hiburan pendidikan berasal dari kata " pendidikan (education)dan entertainment ( hiburan)". Oleh karena itu, hiburan pendidikan dalam artian bahasa berarti pendidikan yang menyenangkan atau menghibur, sedangkan dari segi terminologi, hiburan pendidikan merupakan proses pembelajaran yang dirancang sedemikian rupa sehingga muatan pendidikan dan hiburan dapat dipadukan secara harmonis sehingga pembelajaran menjadi menyenangkan. Bersenang-senang belajar ini biasanya dilakukan dengan humor, bermain ( permainan), kinerja ( permainan dari peran ) dan pernyataan. Perpaduan antara belajar dan bermain mengacu pada sifat alami anak yang dunianya adalah dunia bermain. Bagi anakanak, jarak belajar dan bermain sangat kecil. Pemilihan model hiburan

pendidikan juga didasarkan pada hasil penelitian fungsi otak. Penemuan baru-baru ini bahwa anak-anak akan belajar secara efektif ketika mereka bersenang-senang dan tanpa tekanan ( pembelajaran revolusioner ). Kelas terapan dikemas dalam lingkungan bermain dan eksperimen sehingga pembelajaran tidak lagi 
membosankan tetapi menjadi arena bermain yang mendidik dan menyenangkan bagi siswa. Permainan selain memiliki fungsi penting untuk kepribadian juga memiliki fungsi sosial dan emosional. Saat bermain, anak mengalami berbagai fungsi sosial dan emosional. Saat bermain, anak mengalami berbagai emosi, kegembiraan, kesedihan, kekecewaan, kebanggaan. Melalui bermain, anak memahami hubungannya dengan lingkungan sosialnya, belajar bersosialisasi dan memahami aturan atau tatanan sosial. Selain itu, aktivitas bermain sangat erat kaitannya dengan perkembangan kognitif anak. Oleh karena itu bermain sangat penting dan memiliki pengaruh yang besar terhadap perkembangan psikologis anak karena bermain juga terjadi dalam proses pembelajaran. Persamaannya adalah perubahan yang terjadi dalam belajar dan bermain yang dapat mengubah perilaku, sikap, dan pengalaman.

Pembelajaran yang menyenangkan bukan sekedar pembelajaran yang menuntut anak untuk tertawa lepas, akan tetapi merupakan pembelajaran yang didalamnya terdapat korelasi antara guru dan siswa dalam lingkungan yang sama sekali tidak ada penekanan hanya ada jaringan komunikasi yang saling mendukung. Pembelajaran yang membebaskan menurut konsep Paulo Faire adalah pembelajaran yang tidak ada lagi tekanan baik fisik maupun psikis, karena setiap tekanan hanya akan membayangi pikiran siswa, sedangkan kebebasan yang diperlukan dapat merangsang penciptaan dari sebuah iklim yang mengarah ke pembelajaran menyenangkan.

Dalam konsep pembelajaran melalui hiburan edukatif, semangat belajar berada dalam proses pembelajaran yang menyenangkan, nyaman dan mengejutkan serta bagaimana hubungan antara guru dan siswa dapat dibangun dengan pendekatan metode berdedikasi yang memiliki "nuansa redagonis" artinya interaksi antara guru dan siswa tidak terjalin dengan komunikasi yang kaku tetapi harmonis, sebagai dosen ia sangat luwes, akrab dan bersahabat seperti halnya dengan teman-temannya sendiri. Dengan cara demikian, siswa tidak merasa dibatasi, takut dan mereka dapat berinteraksi dengan kebebasan dan kegembiraan.

Kegiatan bermain untuk anak-anak adalah proses pendidikan dan pengajaran, karena mainan mencerminkan sarana realisasi diri yang efektif dan berhasil, tidak hanya tingkat pendidikan yang menjadi dasar untuk pengembangan kepribadian yang baik tetapi juga kegiatan bermain mereka juga dapat mempengaruhi keterampilan dan kemampuan anak-anak. Tindakan dan pengetahuan anak dilihat dari pemikirannya, kekuatan daya ingat, imajinasi dan pengetahuan kausalitas yang membantu anak untuk bergerak dan berinovasi. 


\section{Metode Outbound}

Outbound adalah permainan/kegiatan yang dapat memberikan perubahan karakter yang lebih baik/positif, misalnya: untuk meningkatkan kualitas kerja karyawan perusahaan melakukan kegiatan outbond bagi karyawannya guna meningkatkan kreativitas, kepemimpinan, kerja tim, ketelitian, disiplin dan sebagainya. Pelaksanaan kegiatan pelatihan kepemimpinan dasar yang dikemas dalam bentuk outbond memiliki tujuan sebagai berikut: melatih jiwa kepemimpinan, kepribadian, sosial dan kewirausahaan bagi calon pemimpin, meningkatkan potensi kepemimpinan, mengubah perilaku, pola pikir, sikap dan tindakan pemimpin potensial berfokus pada keterampilan berdasarkan hasil pemetaan yang dikemas dalam bentuk tugas atau permainan (games).

Dalam pelaksanaan permainan harus ada nilai utama (play set) yang harus dicapai, contoh: kemungkinan pengelola adalah mahasiswa yang dalam kesehariannya kesulitan mencapai kampus tepat waktu sehingga tujuan dalam outbond ini adalah kedisiplinan dan nilai lain sebagai nilai pendukung yang harus relevan (saling terkait).

\section{Pendekatan Pendidikan Hiburan Dengan}

\section{Metode Outbound}

Kelas diterapkan dikemas dalam lingkungan game dan eksperimen sehingga pembelajaran tidak membosankan lagi. Pelaksanaan kegiatan pelatihan kepemimpinan dasar dilakukan melalui simulasi permainan sedangkan permainan dikemas dengan membuat beberapa tim dimana terdapat seorang pemimpin atau pemimpin tim dalam tim dan setiap tim harus melakukan sudut insentif yang ditampilkan dan dinilai oleh juri. Setiap tim selain teriak juga mendapat beberapa tugas yang diurutkan sesuai tahapan permainan dari yang ringan menjadi semakin sulit sehingga terbentuk kesepakatan tim dan strategi untuk memenangkan pertandingan, dan hal ini menyebabkan terjadinya persaingan antar tim, itulah yang disebut pendekatan hiburan pendidikan dengan metode outbond dimana ada upaya untuk menjadi tim yang handal dan ada persaingan antar tim atau grup.

\section{HASIL DAN PEMBAHASAN}

\section{Deskripsi Kondisi Awal}

Untuk memverifikasi kondisi motivasi awal mahasiswa D-III Sekretari Universitas Pamulang Semester 1 dan 2, instrumen yang digunakan adalah bentuk observasi motivasi. Hasil pemilihan kondisi 
motivasi awal untuk semua peserta Latihan Dasar Kepemimpinan dapat dilihat pada lampiran.

Berdasarkan lampiran, dari 32 peserta Diklat Kepemimpinan Dasar tahun 2 020 dapat diketahui beberapa hal sebagai berikut:

1. Nilai motivasi awal tertinggi pada jumlah peserta 32 (tiga puluh dua) orang yaitu 67.

2. Nilai motivasi terendah awal nilai dari yang 32 (tiga puluh dua) peserta adalah 61 .

3. Nilai rata-rata motivasi awal nilai dari yang 32 (tiga puluh dua) peserta adalah 64 .

\section{Deskripsi Siklus 1}

Kegiatan penelitian Latihan Dasar Kepemimpinan terdiri dari dua siklus, hal ini disebabkan terbatasnya waktu yang tersedia dan dengan dua siklus penelitian penulis menganggap cukup untuk melaksanakan penelitian.

Kegiatan yang akan dilakukan pada setiap siklus adalah: tahap perencanaan, tahap pelaksanaan, tahap observasi dan evaluasi dan tahap refleksi.

\section{Tahap Perencanaan Penelitian}

Dalam penelitian ini penulis menyusun rencana tindakan sebagai berikut:
1. Merumuskan masalah yang dicari solusinya. Dalam penelitian tindakan ini, masalah yang akan dipecahkan menyangkut motivasi dan kompetensi mahasiswa dalam mengikuti pelatihan kepemimpinan dasar.

2. Merumuskan tujuan pemecahan masalah untuk memenuhi tantangan motivasi/tindakan. Dalam penelitian ini penulis menguraikan rencana tindakan menggunakan pendekatan hiburan edukatif dengan metode outbound berupa permainan dalam ruang.

3. Pada saat merumuskan indikator keberhasilan dalam penelitian tindakan diklat kepemimpinan dasar maka indikator keberhasilan pelaksanaan tindakan ini penulis tetapkan sebesar $71 \%$ yang artinya tindakan ini dinyatakan berhasil jika $71 \%$ peserta diklat mampu mengikuti pelatihan kepemimpinan dasar

4. Melakukan Identifikasi metode pengumpulan data yang akan digunakan. Metode pengumpulan data yang digunakan adalah data kualitatif melalui observasi motivasi dan kompetensi peserta diklat kepemimpinan dasar dalam mengikuti kepemimpinan dasar. 
Tahap Pelaksanaan Penelitian

Tahap ini merupakan tahap sentral dimana pelatihan berlangsung dengan menggunakan pendekatan hiburan edukatif dengan metode outbound, langkahlangkahnya sebagai berikut:

1. Peneliti sebagai fasilitator pelatihan dasar kepemimpinan berdoa sebelum kegiatan dimulai.

2. Sebagai penyemangat sebelum dimulainya diklat kepemimpinan dasar dimainkan lagu dan gerakan yang diikuti oleh seluruh peserta agar tubuh lebih segar dan lebih siap menerima materi.

3. Sebelum menyampaikan materi, peneliti memberikan pre-test untuk mengukur tingkat pengetahuan peserta mengenai materi pelatihan kepemimpinan.

4. Peneliti menjelaskan pengertian pelatihan kepemimpinan yang dikemas dengan pendekatan pendidikan dan hibur an melalui pendekatan outbound.

5. Peneliti membagi peserta menjadi kelompok atau suku dan memberi identitas etnis atau kelompok dengan bendera dan pita yang ditempelkan pada anggota semua anggota kelompok atau suku.

6. Peserta kemudian diberi tugas membuat lagu dan nyanyian suku agar mereka bersemangat untuk menyelesaikan tugas di dalam dan di luar kelas.
7. Penyajian hasil kelompok dalam nyanyian suku dan nyanyian tiap suku secara bergantian.

\section{Tahap Observasi / Observasi}

Kegiatan observasi dalam penelitian ini dilakukan bersamaan dengan pelaksanaan tindakan, yaitu, pada saat pelatihan menggunakan edutainment metode outbond untuk 32 peserta. Kegiatan observasi dalam penelitian ini untuk mengetahui kolaborasi, kreativitas, motivasi, perhatian serta presentasi peserta latihan dasar kepemimpinan.

Pengamatan dilakukan dengan menggunakan lembar observasi. Dari hasil observasi terhadap sikap peserta pada saat diklat menggunakan pendekatan edukasi entertainment dengan metode outbound, adapun langkah observasi sebagai berikut:

1. Latihan dasar kepemimpinan adalah pelatihan dasar kepemimpinan mahasiswa Sekretari D- III yang berlangsung selama 26 (dua puluh enam) jam pelatihan dasar dalam kepemimpinan tujuh puluh (70) jam pelatihan dasar kepemimpinan umum.

2. Melakukan observasi untuk melihat perkembangan motivasi peserta diklat kepemimpinan dasar mahasiswa Program Studi D-III Sekretari Tahun 2020 pada siklus 1 sedangkan nilai motivasi 
tertinggi pada siklus 1 adalah 79,67, terendah 74,33 dan nilai rata-rata 76,90.

3. Melakukan asesmen dan observasi untuk memverifikasi perkembangan kompetensi peserta diklat kepemimpinan dasar mahasiswa D III Sekretari tahun 2020, pada siklus 1 skor kecakapan tertinggi pada siklus 1 adalah 80 , terendah adalah 74 dan nilai rata-rata adalah 77 .

\section{Refleksi ( Reflektif )}

Berdasarkan hasil observasi yang dilakukan selama kegiatan dan hasil evaluasi pada pertemuan akhir siklus I dilakukan refleksi. Hasil refleksi ini akan dijadikan acuan dalam merencanakan perbaikan untuk siklus selanjutnya. Semua tahapan kegiatan tersebut mulai dari tahapan perencanaan, pelaksanaan dan observasi serta evaluasi dilakukan secara berulang-ulang melalui siklus-siklus hingga terjadi peningkatan sesuai yang diharapkan yaitu mencapai skor kategori "memuaskan" dengan skor lebih besar dari 71. Jika skor yang diperoleh kurang dari 71 berarti tujuan yang ditetapkan belum tercapai maka perlu dilakukan tindakan pada siklus II.

Setelah nilai diperoleh, nilai ditransfer secara kualitatif untuk memberikan umpan balik pada kualitas sikap peserta pelatihan dasar yang diamati dalam pelatihan

kepemimpinan menggunakan edutainment dengan metode outbound.

Sebagai keputusan akhir untuk menentukan kelulusan peserta pelatihan kepemimpinan dasar mahasiswa Program Studi Sekretari D-III tahun 2020, skala nilai berikut yang digunakan:

\begin{tabular}{|c|c|l|}
\hline ANGKA & ALFABET & LATIHAN \\
\hline $86-100$ & SEBUAH & $\begin{array}{l}\text { SANGAT } \\
\text { PUAS }\end{array}$ \\
\hline $71-86$ & Iya & MEMUASKAN \\
\hline$<70$ & C & $\begin{array}{l}\text { KURANG } \\
\text { MEMUASKAN }\end{array}$ \\
\hline
\end{tabular}

Pada akhir siklus pertama selain

sukses juga terdapat kegagalan yang dialami sebagai berikut:

1. Saat menerapkan pendekatan hiburan edukatif dengan metode outbound melal ui penugasan kelas bagi peserta terdapat kecenderungan hanya sedikit anggota yang aktif mengikuti pelatihan dasar kepemimpinan.

2. Minimnya motivasi mengikuti tugas di dalam ruangan disebabkan karena ruang yang sangat sempit sehingga membuat peserta tidak dapat bergerak dengan leluasa.

3. Peneliti menilai bahwa penerapan pendekatan hiburan edukatif dengan metode outbond di kelas belum dapat memaksimalkan potensi 
atau kompetensi peserta diklat kepemimpinan dasar dalam mengikuti materi diklat dasar kepemimpinan. Untuk hasil yang baik pada kegiatan pembelajaran selanjutnya pada siklus 1 hasil kurang optimal, pada siklus 2 peneliti merubah tugas dikelas menjadi penugasan di luar kelas.

\section{Deskripsi Siklus 2}

Siklus 2 berdurasi 13 (tiga belas) jam @ 45 menit, durasi siklus 2 terdiri dari 4 (empat) tahapan, yaitu: perencanaan, pelaksanaan, observasi dan refleksi. Dalam penerapan siklus 2 sesuai langkah-langkah siklus 1 adalah sebagai berikut:

\section{Perencanaan Penelitian}

Perencanaan (planning) siklus 2 didasarkan pada perencanaan ulang pada siklus 1 sebagai berikut:

1. Kegiatan di dalam dan di luar kelas dirubah menggunakan pendekatan edutainment dengan metode outbound.

2. Pembimbingan fasilitator di luar kelas direncanakan untuk lebih intensif.

3. Memberikan reward kepada kelompok yang hasil kerjanya terbaik.

\section{Tahap Pelaksanaan Penelitian}

1. Memberikan rangsangan atau motivasi seperti menyanyikan sebuah lagu dan menari sebelum fasilitator memberikan tugas di luar kelas.

2. Melakukan review tugas kelompok siklus 1 untuk mengetahui pemahaman peserta akan materi yang diberikan.

\section{Pengamatan / Observasi}

Kegiatan observasi siklus 2 dilaksanakan bersamaan dengan pelaksanaan tindakan yaitu pada saat pelatihan menggunakan pendekatan edutainment deng an metode outbond di luar kelas sebanyak 32 peserta. Kegiatan observasi dalam penelitian ini bertujuan untuk mengetahui motivasi dan kompetensi peserta diklat kepemimpinan dasar pada tugas-tugas di luar kelas. Pengamatan dilakukan dengan menggunakan lembar observasi. Dari hasil observasi terhadap sikap peserta pada saat diklat menggunakan pendekatan hiburan edukatif melalui metode outbond dengan penugasan diluar kelas dengan langkah observasi sebagai berikut:

1. Melakukan observasi untuk memverifikasi keseriusan, kekompakan dan antusiasme peserta dalam pekerjaan (permainan) yang dilaksanakan di luar ruangan.

2. Pada siklus 2 nilai motivasi tertinggi 85 , terendah 79 dan nilai rata-rata 82

3. Melakukan asesmen dan observasi untuk melihat perkembangan kompetensi 
peserta latihan dasar kepemimpinan adapun nilai kompetensi siklus 2: tertinggi 91 , terendah 88 dan rata-rata 90 .

\section{Refleksi ( Reflektif )}

Berdasarkan hasil observasi selama kegiatan dan hasil evaluasi pada pertemuan akhir siklus 2 dilakukan refleksi. Hasil refleksi akan dijadikan acuan untuk perencanaan perbaikan atau perbaikan pada siklus berikutnya. Seluruh tahapan kegiatan tersebut mulai dari tahap perencanaan, pelaksanaan dan observasi serta evaluasi dilakukan secara berulang-ulang melalui siklus-siklus hingga terjadi peningkatan sesuai yang diharapkan, yaitu mencapai skor kategori "memuaskan" dengan skor lebih dari 71. Jika skor yang diperoleh kurang dari 71 artinya tujuan yang ditetapkan belum tercapai.

Setelah diperoleh nilai, nilai tersebut ditransfer ke dalam bentuk kualitatif untuk memberikan masukan tentang motivasi dan kompetensi peserta diklat kepemimpinan dasar yang diamati dalam diklat menggunakan pendekatan edutainment deng an metode outbound. Kriteria evaluasi mengacu pada nilai persetujuan peserta diklat kepemimpinan dasar.

\section{Pembahasan}

Peningkatan motivasi dan kompetensi peserta pelatihan kepemimpinan dasar mahasiswa Prodi Sekretari D-III 2020 dapat dilihat pada data yang diverifikasi dalam kondisi awal, siklus 1 siklus 2: pada siklus 1 peserta memperoleh nilai rata-rata 64 pada kondisi awal meningkat menjadi 77 pada siklus 1 menjadi 82 pada siklus 2 untuk nilai motivasi, sedangkan nilai kompetensi 62 pada kondisi awal menjadi 77 untuk siklus 1 dan 90 pada siklus 2. Oleh karena itu, penerapan edutainment dengan metode outbound dapat meningkatkan motivasi dan kompetensi kepemimpinan pelatihan dasar kepemimpinan mahasiswa Prodi DIII Sekretari Tahun 2020.

\section{PENUTUP}

\section{Kesimpulan}

Berdasarkan hasil penelitian tindakan latihan dasar kepemimpinan pada latihan dasar kepemimpinan mahasiswa Prodi D-III Sekretari tahun 2020 dapat disimpulkan sebagai berikut:

1. Motivasi peserta latihan dasar kepemimpinan dapat ditingkatkan melalui penerapan pendekatan edutainment dengan metode outbound. Hal ini terlihat dengan meningkatnya 
nilai rata-rata kondisi awal dari 64 menjadi 82.

2. Kompetensi peserta latihan dasar kepemimpinan dapat ditingkatkan melalui penerapan pendekatan edutainment dengan metode outbound. Hal ini terlihat dengan meningkatnya nilai rata-rata kondisi awal dari 64 menjadi 90.

3. Motivasi dan kompetensi peserta latihan dasar kepemimpinan dapat ditingkatkan melalui penerapan pendekatan edutainment dengan metode outbound.

\section{Saran}

Berdasarkan hasil penelitian pada tindakan pelatihan kepemimpinan dasar melalui edutainment dengan metode outbond itu dapat meningkatkan kualitas mahasiswa dalam pengembangan diri dan motivasi untuk peningkatan wawasan dalam organisasi , adapun saran yang dapat peneliti sampaikan sebagai berikut:

1. Fasilitator latihan dasar kepemimpinan dapat menerapkan pendekatan edutainment dengan metode outbound pada proses pembelajaran latihan dasar kepemimpinan.

2. Perlu adanya penelitian dan pengkajian sejenis yang berkaitan dengan penerapan pendekatan edutainment dengan metode outbound.
3. Perlu adanya variasi dalam penerapan metode dalam pelaksanaan latihan dasar kepemimpinan untuk meningkatkan motivasi dan kompetensi belajar mahasiswa.

\section{DAFTAR PUSTAKA}

\section{Sumber Buku}

Afifudin dan Beni Ahmad. 2010. Metode penelitian kualitatif . Bandung:

Perpustakaan Setia.

Arikunto, Suharsimi. 2010. Prosedur investigasi . Jakarta: Rineka Cipta.

Arikunto, Suharsimi. 2011. Dasar-dasar penilaian pendidikan. Jakarta: Literasi Bumi.

Asti, Baidatul

Muchlisin. 2010. Fun Outbound:

Desain kegiatan outbound

yang efektif. Yogyakarta: Diva Press.

Bungin, M. Burhan, Prof, Dr, H, S.Sos, M.Si. 2010. Metode penelitian kuantitatif. Jakarta: Prenada Media.

Darajat Zakiyah. 2010. Metodologi dan Pembelajaran . Jakarta: Literasi Bumi.

Daryanto. 2011. Penelitian tindakan dalam penelitian tindakan kelas dan sekolah. Yogyakarta: Gava Media.

Kementerian

Pendidikan

Nasional. 2010. Pedoman pendidikan dan pelatihan berbasis kompetensi. Jakarta: Direktorat Pendidikan dan Pelatihan.

Kementerian Pendidikan Nasional. 2010. Pendidikan dan pelatihan berbasis kompetensi. Jakarta: Direktorat Pendidikan dan Pelatihan Kapita Selekta.

Dimyati dan Mudjiono. 2010. Belajar dan belajar. Jakarta: Rineka Cipta. 
Djamarah, Syaiful Bahri. 2010. Strategi belajar mengajar. Jakarta: Rineka Cipta.

Hamid Sholeh. 2011. Metode hiburan pendidikan . Yogyakarta: Diva Press.

Hamruni. 2010 . Konsep hiburan pendidikan dalam pendidikan Islam. Yogyakarta: Kompensasi untuk sukses.

Iskandar. 2011. Metodologi Penelitian Pendidikan dan Sosial (kuantitatif dan kualitatif) . Jakarta: GP Press.

Kurniawan, Hananto. 2010. Pengaruh Game Outbound terhadap Kemampuan Berpikir Remaja di SMPN 1 Buluwalang Malang . Uji. (Tidakditerbitkan). Mala ng: Universitas Negeri Malang. (Di barisan). ( http://karyailmiah.um.ac.id/i ndex.php/ diunduh 1 Agustus 2020 jam 10:30 pagi)

Mahmud. 2011. Metode penelitian pendidikan. Bandung: CV Pustaka Setia.

Muhammad, As'adi. 2010. Kekuatan pelatihan ekster nal. Yogyakarta: Power Books.

Purwanto, $\quad$ Ngalim. 2011. Psikologi pendidikan . Bandung: CV Remadja Karya.

Sutrisno. 2010. Revolusi Pendidikan di Indonesia: Pembedahan Metode dan Teknik Pendidikan Berbasis Kompetensi. Yogyakarta: Ar-Ruzz 